\title{
Chapter 2 \\ The moving target of activism: Changing language ecologies in the Isthmus of Tehuantepec
}

In 2013 the Mexican Law on the Linguistic Rights of Indigenous People, which officially recognizes Indigenous languages like Isthmus Zapotec as "national languages”, turned 10 years old. When a 2-week Diidxazá literacy workshop, Camino de la Iguana, was taught that spring by Juchitán-based language activists Natalia Toledo and Víctor Cata in Gui'xhi' ro' (Big mountain/ hill in Zapotec, also known officially as Álvaro Obregon), a rural town about 40 minutes outside of Juchitán de Zaragoza in the Isthmus of Tehuantepec, Oaxaca, most of the children who attended were the same age as the law, some a few years older or younger, and all of them spoke Isthmus Zapotec as their preferred form of communication. When it came to writing it was another story however; when told to write a poem or an autobiography, students repeatedly asked the Diidxazáspeaking teachers if they should write in diidxazá [Zapotec] or diidxastia [Spanish]. Some wrote in Spanish even when told several times to write in Zapotec. After years in a Spanish-only education system, for many students writing seemed to be synonymous with Spanish, while the new vowels and consonants being taught by the Zapotec-speaking, yet cosmopolitan-looking teachers who arrived in a taxi from the urban hub of Juchitán (with an unusual foreigner in tow), were unfamiliar. Some students took to Zapotec writing and reading more than others, and the teachers encouraged them to follow in the footsteps of past and present Isthmus Zapotec literary figures, giving them booklets with some well-known Diidxazá poetry. They reminded the students that a man from their town, in fact the father of 2 of the students, was one of the winners of a competition for Zapotec writers hosted by a non-governmental arts foundation in the state capitol a few years previously, and that writers from the Isthmus Zapotec community have won this award more often than writers from other Zapotec communities. Several public school teachers also participated in the workshop on their own initiative (and their own time), telling me in conversation after the workshop that they would like to include Isthmus Zapotec in their classes more, but that they were not confident in writing it.

The challenging learning curve for Isthmus Zapotec speakers being taught a written norm for the first time was visible in every iteration of the literacy 
workshop that I observed over the following year and a half, with Isthmus Zapotec speakers consistently more comfortable reading and writing in Spanish due to the predominance of Spanish in schooling and the linguistic landscape. The age of the speakers in the workshops changed, however; in some parts of the Isthmus the youngest speakers participating in the workshop were in their 20s; in other areas in their 30s or 40s; and in others in their 50s and 60s. I learned that Gui'xhi' ro' was one of only a few towns where a majority of children spoke Zapotec. Children always showed up to participate in the literacy workshops, often with more gusto than the adults, but in many locations the children were speakers of Spanish who understood a few Isthmus Zapotec words or phrases, if any. Some came from families who had immigrated to the region, with parents who were also speakers of Spanish or of another Indigenous language, while the majority came from Istmeño families and had been raised in Spanish by Zapotec-speaking parents and grandparents.

I was told time and again that Diidxazá is not being passed on in the Isthmus because many people think it is a dialecto (a lesser form of communication) and that if children grow up speaking it they will not speak Spanish well, or have a hard time learning Spanish. Through observation it became clear that raising children predominantly in Spanish was currently the practice among a majority of the population. As one mother commented,

Mis hijos, la niña de 12 años y el niño de 9, no hablan el zapoteco. Ya hace como 10 años que los niños que vienen naciendo, a partir de 10 años atrás, ya no están hablando, ya no están aprendiendo el zapoteco, ya nosotros los papás como que les hablamos más en el español, para no confundirlos con el zapoteco. Porque a veces cuando nosotros, en mi caso no, que desde niña hable el zapoteco, y aprender el español sí fue un poco complicado, porque, aquí en Juchitán decíamos, en La Ventosa es. . ., por el tono del zapoteco, siempre teníamos mal entre el español y zapoteco, la mezcla del español y zapoteco, era muy difícil. Pues la gente que según esto ya sabía mucho, se le parecía como naco, pues hablar así, sí, sí daba un poco de vergüenza.

My children, the 12-year-old girl and 9-year-old boy, don't speak Zapotec. Now for about 10 years the children who are being born, since 10 years ago, now they're not speaking, now they're not learning Zapotec, now we, the parents, it's like we speak to them more in Spanish, so as not to confuse them with Zapotec. Because sometimes when we, in my case, that since childhood I spoke Zapotec and learning Spanish was a bit complicated, because here in Juchitán we said, in La Ventosa um. . . because of the tone of Zapotec we always had trouble between Spanish and Zapotec, the mix of Spanish and Zapotec, it was really difficult. Well the people who apparently already knew a lot, it appeared to them like naco [uncouth, low class], to speak like that, yes, yes it gave some shame.

(Interview November 2013) 
Although this mother brought her daughter to one of the Zapotec literacy workshops, I observed her interacting only in Spanish with her daughter. The girl only attended a few days of the workshop however, and her mother told me she stopped coming because she had too much homework. When I visited their home a month later the girl was indeed busy with her homework, in particular her English homework (on that occasion she was struggling to understand a decontextualized paragraph about Amelia Earhart) which she said was always challenging and time consuming. In contrast, the girl told me that she does understand everything her parents say in Zapotec, she just does not speak it herself. Again and again I observed this practice of using only Spanish with children, as well as the willingness to invest more time in learning English than learning Isthmus Zapotec.

Through this glimpse of language practices, and others to follow, I will attempt to illustrate the language ecology (Haugen 1972; Fill and Muhlhausler 2001) of the Isthmus of Tehuantepec. There are multiple agents, contexts, and processes across different social scales which make up a language ecology (Hornberger and Johnson 2007). For example, echoes of international, national, regional and local efforts to promote Indigenous languages- such as the global imperialism of English, the 2013 Mexican law, the Oaxaca state-level writing competition, and the non-formal literacy workshop created by local actors- are all present in the Isthmus. However, a well-established trend away from Indigenous language use and towards greater valuing of Spanish in public, and increasingly in private spaces, is also very apparent, as is pressure to learn English for future schooling and employment opportunities. The communicative repertoires of children in the Isthmus in the early 21st century range from preferring Isthmus Zapotec to preferring Spanish to varying degrees, and the aspirations of members of the speech community likewise vary. These paradoxes are not new: the language ecology of the Isthmus of Tehuantepec has long been multilingual and fraught with political tensions.

Taking a historically embedded and contextualized view of such a language ecology, it becomes clear that linguistic equality must be interpreted in relation to each historical moment, and that forms of exclusion and inequality may be produced through different mechanisms and actors. From the dominance of certain varieties of Zapotec over others to the imposition of Spanish, and more recently English, in Mexican schools, language hierarchies have continued to shift over time. Advocating for linguistic equality is consequently a historically-contingent endeavor, with a moving target that must be understood in relation to the prevailing power dynamics and the communicative repertoires and aspirations of people at a given time. The political environment in Mexico and in the Isthmus has shifted in recent decades to promote Indigenous language use in more 
ways, while in other ways it has remained discriminatory, as discussed further below. With numerous Indigenous languages and a history of local resistance to colonial imposition, it can be challenging to tease out the interwoven stories around language use, language politics and education in the Isthmus, and to determine appropriate activism strategies. At the same time, it also makes the region of especial interest in studies of Indigenous education, language activism and politics. In this chapter I give a brief background to language use in the Isthmus of Tehuantepec from the pre-colonial period through the present, highlighting shifting patterns of inequality and exclusion (2.1-2.5). I further analyze language practices in the Isthmus and the linguistic landscape in order to sketch the regional language ecology at the time of my study (2.6). Understanding this context is a pre-requisite for insight into both the characteristics of diverse activism initiatives, and the place and people who constitute them. In conclusion, I discuss the challenges and affordances of understanding linguistic equality as a moving target embedded within a changing language ecology (2.7).

\subsection{Indigenous multilingualisms: Pre-colonial language ecologies}

The territory that is now Mexico has been inhabited by numerous sociolinguistic groups, who have come into contact and sometimes conflict over many centuries. A common way of identifying and dividing social groups in Mexico is through classifying their communicative practices into categories of language families and languages- the essentialist paradigms of enumeration and categorization discussed in chapter 1. Following this dominant perspective, there are 11 language families and a debated number of languages spoken in Mexico today (the current official estimate being 68 languages with 364 variants (Instituto Nacional de Lenguas Indígenas (INALI) 2008)). Oaxaca state is one of the regions of Mexico with the greatest linguistic and cultural diversity, with 16 ethnic groups and a debated number of languages (Barabas and Bartolomé 1999). Figure 3 illustrates Mexico, the state of Oaxaca, the state capital Oaxaca city, and the city of Juchitán. Juchitán is in the Isthmus of Tehuantepec, the region of land where the distance between the Gulf of Mexico and the Pacific Ocean is the shortest. 


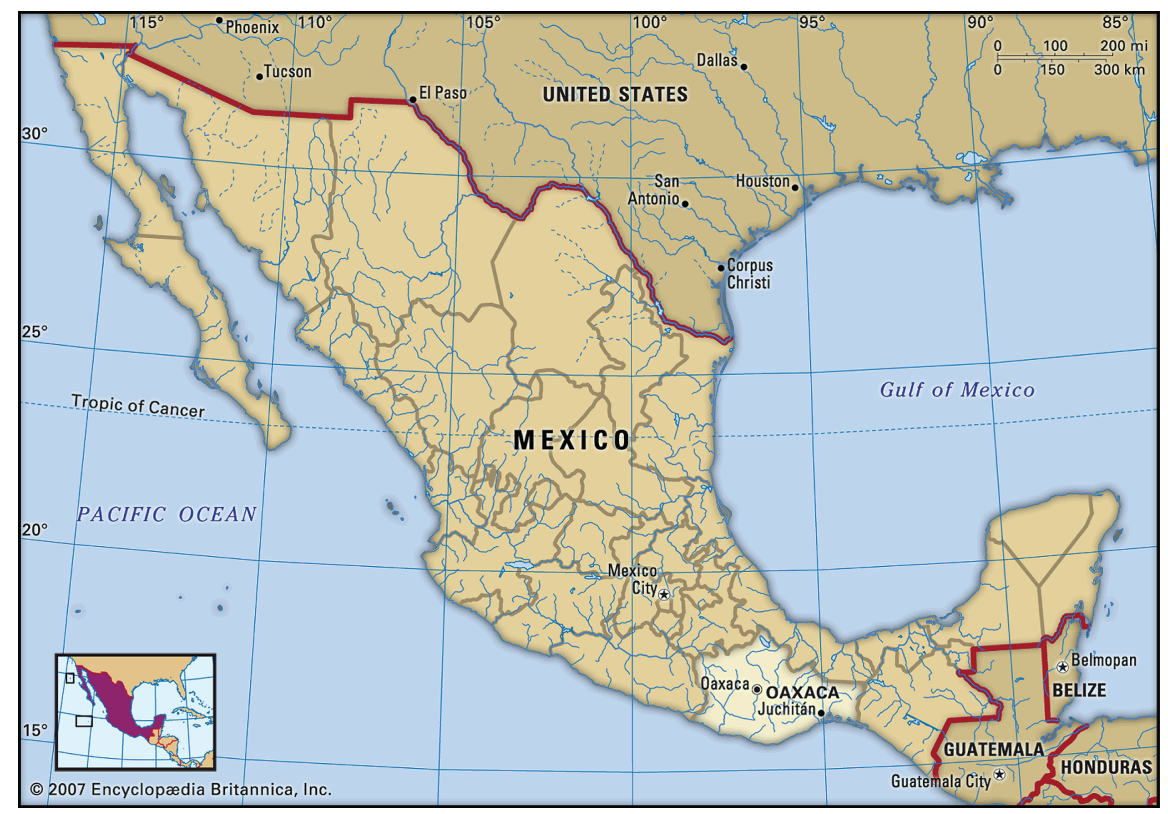

Figure 3: The country of Mexico, highlighting the state of Oaxaca and the city of Juchitán. ${ }^{8}$

Five languages are present in the Isthmus, hailing from 4 different families: Ayuuk (Mixe) and Zoque (both from the Mixe-Zoque family), Zapotec (Oto-manguean family), Ombeayiüts (Huave) (isolate) and Chontal (isolate). ${ }^{9}$ The rough geographic distribution of these languages, as well as the other Indigenous languages of Oaxaca is illustrated in more detail in Figure 4. Zapotec languages or variants cover the largest section of the state. After Nahuatl and Yucatec Maya, Zapotec is considered the Indigenous language with most speakers in Mexico (441,769 according to the Ethnologue (Lewis, Simons, and Fennig 2015)), although these figures overlook the internal diversity and lack of intelligibility between some varieties of Zapotec. Zapotec is considered a language group with four main sub-divisions and roughly 62 variants, many of which are not mutually intelligible (Pérez Báez 2011; Pérez Báez and Kaufman 2016). The

8 Map reprinted with permission from Encyclopædia Britannica, (C) 2007 by Encyclopædia Britannica, Inc.

9 I attempt to use auto-determinations of Indigenous groups in addition to the names used in Spanish as much as possible, although I acknowledge that preferences for these names can vary within each group. Here I use the auto-determinations which I heard most frequently during my study. 


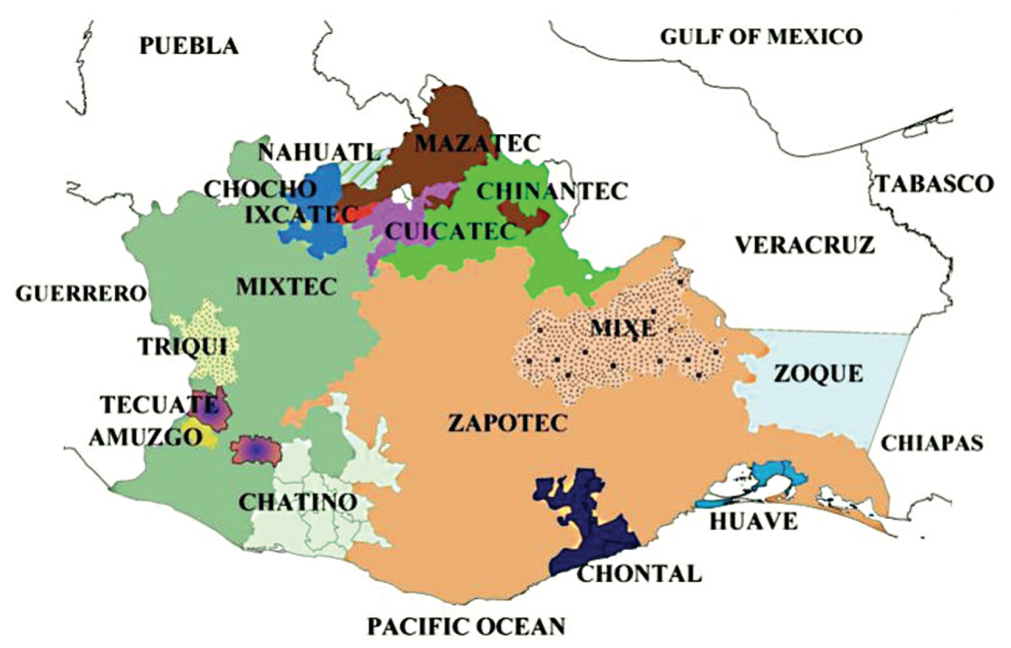

Figure 4: Map of Indigenous languages of Oaxaca. ${ }^{10}$

four varieties are Isthmus Zapotec across the coastal plain of the Isthmus, Sierra Sur Zapotec in the southern mountains, Valley Zapotec in the central valleys where the state capital Oaxaca City is located, and Sierra Juárez Zapotec in the northern mountains (Barabas and Bartolomé 1999). In Figure 4 the position of Isthmus Zapotec is visible in between the Huave or Ombeayiüts zone along the coast, the Chontal zone along the coast to the west, the Ayuuk/ Mixe zone in the mountains to the north, and the Zoque zone in the mountains to the northeast.

The geographical spread and relatively large number of speakers of Zapotec today is an echo of the presence and power of the Zapotec empire in precolonial Mesoamerica. Zapotecs developed a wealthy and hierarchical empire, governing much of what is now Oaxaca from around 500 BCE to $900 \mathrm{CE}$. The oldest signs of habitation in the central valleys of Oaxaca date from 950 BCE, where density and social organization continued to develop, partially through contact with Olmec civilization between 1200-900 BCE. Around 400 BCE what would become the imperial city of Monte Alban was founded on a mountaintop at the intersection of several valleys (Barabas and Bartolomé 1999: 62-63) overlooking the site of the state capital today. The auto-denomination Binnizá, "cloud people" (binni [people] $z a ́$ [cloud]), now used in the Isthmus, as well as the auto-

10 Map by Felipe H. Lopéz. Reproduced with permission from Munro, Pamela, Brook Danielle Lillehaugen, and Felipe H Lopez. 2007. Cali Chiu? A Course in Valley Zapotec. Lulu.com. 
denomination of the Isthmus Zapotec language Diidxazá (diidxa [word/ language] $z a$ [cloud]) could have been inspired by the dramatic clouds that form a striking part of the landscape in the Oaxacan mountains. Covarrubias (1946) in his classic study of southern Oaxaca notes that Zapotecs in particular have no origin or migration story, but claim to originate in the region. He quotes an early historian, who wrote "I have found no reference, with semblance of truth, of the first arrival of this nation, nor of the origin of their lords, from which it may be deduced they were very ancient . . . To boast of bravery they claimed to be sons of jaguars and other wild beasts; if they were great chiefs of ancient lineage they considered themselves descendants of old and shady trees; those that were proud of being untamable and stubborn, said they were born of rocks and cliffs ..." (174).

The Zapotec empire produced significant achievements in architecture, astronomy, medicine, and writing, with up to 30,000 people residing in Monte Alban at its peak (Barabas and Bartolomé 1999: 63). Like the Aztec and Mayan empires, the Zapotecs had a sophisticated calendar, a base-20 numerical system, advanced architecture, and writing which was used in elite circles (de la Cruz 2008). The first phase of Zapotec writing is dated from 600 BCE to 800 CE, and included semi-phonetic writing as well as logographic or hieroglyphic writing (de la Cruz 2008:12). A second phase is identified from 800 CE to the Spanish invasion in $1521 \mathrm{CE}$, consisting of symbolic or pictographic representations (de la Cruz 2008:13). De la Cruz questions why Zapotec writing seemingly regressed from more sophisticated phonetic representations to pictographic representations, and proposes the hypothesis that it was due to:

la multiplicidad lingüística existente en el territorio dominado por los binnigulaa'sa': sacrificaron el apego a la gramática de su lengua, para usar una forma de escritura que pasaba directamente del signo visual- sin referencia a los sonidos de una sola lengua- a la imagen mental que generaban los pictogramas o ideogramas

the linguistic multiplicity existing in the territory dominated by the ancient Zapotecs: they sacrificed the attachment to the grammar of their language in order to use a form of writing that passed directly from the visual sign- without reference to the sounds of a single language- to the mental image that generated the pictographs or ideographs.

(2008: 13)

Whatever the motivations for change, Romero Frizzi (2003) notes that the Zapotecs were among the first Mesoamerican civilizations to develop writing, and almost certainly influenced other civilizations whose writing systems are now better known. The pre-colonial Zapotec writing system is not fully understood at present, there being fewer remnants than there are of Maya (Urcid 2005). 
Monte Alban began to decline for reasons that probably included political conflict and environmental stress, resulting in a shift to networks of smaller city-states throughout the valleys. Zapotecs from the valley city-state of Zaachila migrated down to the Isthmus around $1400 \mathrm{CE}$ as the Aztec influence was strengthening in the region (de la Cruz 2008: 56-57). They displaced the Ikoots or Huave who were believed to have been living there, took over the fertile plain, and began to dominate economic trade in the region. The Ikoots territory was reduced to a narrow strip of land by the ocean and they were subject to general discrimination by many Zapotec. The Zapotecs who settled in the Isthmus ruled from a city-state based in Tehuantepec and maintained contact with other Zapotec seats of power in the mountains and central valleys. Their power was not unilateral and they were not the only Indigenous group to expert dominance over other groups however; by 1486 CE the Aztec had founded the garrison of Huaxyacac (now Oaxaca City) in the central valleys and were extracting tributes from Zapotecs, Mixtecs, and others throughout the greater Oaxaca region (Barabas and Bartolomé 1999: 64). Already in 1484 the Aztec recorded the towns of Tehuantepec and Juchitán in the Mendocino codex as places where they extracted tribute (Ruíz Martínez 2013). Juchitán was represented with the symbol of a flower that has been interpreted as guie' xhuuba, a fragrant flowering tree unique to the region, and given the Nahuatl name Ixtcxochitlán (place of white flowers) (Ruíz Martinez 2013: 17-18), which is the presumed origin of the name Juchitán. ${ }^{11}$ Tehuantepec means Jaguar Hill in Nahuatl, and a large hill that borders the town still bears the same Zapotec name today (Dani Beedxe), indicating the likely bilingualism of at least some of the residents at the time. Despite the military dominance of the Aztec, the regional Zapotec rulers still wielded considerable power in the Isthmus, where the king Cosijoeza banded with the Nuu Savi (Mixtec) and successfully resisted an attack from the Aztec army in the Guie, Ngoola fortress near Tehuantepec, brought on by the Zapotecs' refusal to pay tribute. Nonetheless, it was primarily the names given through the process of internal colonization by the Aztec that were recorded and are in use today, an enduring symbol of the waves of displacement and dominance among Indigenous groups in the region. These struggles amidst Mesoamerican powers took an unpredictable turn a few decades later however with the beginning of the Spanish invasion in 1519 (Miano Borruso 2002).

11 One of the current names for the city is Guidxi Guie', town of flowers, along with Lahuiguidxi, central town, and Xavizende, a zapotecization of San Vincente, the patron saint of the city. 


\subsection{From languages to dialectos: Colonial language ecologies}

Under Spanish colonization the Isthmus became part of the Marquesado del Valle, and was developed for cattle ranching, as well as trans-oceanic trade. Although records of Zapotec life under colonial rule are sparse, it was generally a time of hardship, including heavy tolls from new diseases and hard labor to pay tributes to the Spanish overlords. In 1521 there were 24,000 Indigenous residents of the Isthmus paying tribute; in 1550 there were 6,000, and only 60 years after the invasion in 1580 the population paying tribute had dropped over $80 \%$ to 4,000 (Acuña 1984, in Barabas and Bartolomé 1999: 71), a dramatic drop in the overall population due to harsh conditions (Tutino 1993). There were rebellions against Spanish exploitation throughout the 16th and 17th centuries, with the most famous being the 1660 rebellion of Tehuantepec, where the Zapotecs succeeded in governing the city for one year before the colonial government retook the city (Miano Borruso 2002). Numerous subsequent rebellions occurred in Juchitán as well, leading to the stereotype that Istmeños, and in particular Juchitecos, are "rebeldes, rudos, y laboriosos" [rebellious, rough, and hard-working] (Barabas and Bartolomé 1999: 72).

While the Spanish began instructing some Indigenous elites in Latin literacy during the colonial period (Heath 1972; Montemayor 2004), there was a general erasure of existing literacy and numeracy practices. "The Spanish conquest obliterated every manifestation of high Indian culture” (Covarrubias 1946: 292) through burning manuscripts and killing people in possession of traditional religious items, contributing to the limited understanding of pre-colonial Zapotec writing today. At the same time, already in the 1500s missionaries in Oaxaca were studying and recording spoken Indigenous languages and using this knowledge in pursuit of evangelization. Fray Juan de Córdova, a Spanishborn Dominican monk who arrived in Oaxaca around 1547, is the best-known of numerous missionaries who produced extensive documentation and linguistic description of the Zapotec then spoken around Oaxaca City (Jiménez Moreno 1942). Of all the varieties of Zapotec, modern-day Isthmus Zapotec is the closest to what Córdova recorded, and his 1578 dictionary is still considered a valuable reference by Zapotec scholars today.

The Latin-based (re)education provided by missionaries to some Indigenous people was not the norm, however; the majority of the population was not engaging in formal education under colonial rule. As Robles (1977) comments, "Una organización predominantemente feudal colocaba a la gran mayoría de aborígenes en posición explotada y marginada de los favores del gran desarrollo de los servicios educativos de entonces" (17). [A predominantly feudal organization placed 
the vast majority of Indigenous people in an exploited position, marginalized from the favors of the great development of educational services of the time]. While excluded from Eurocentric education, Indigenous groups were perpetuating their own education through oral and communal forms of teaching and socializing youth, however. Maldonado Alvarado (2002) argues that

\begin{abstract}
Aunque los zapotecos fueron una cultura dominante en tiempos prehispánicos, la mayoría de su población organizaba la vida de manera oral mientras que las minorías en el poder desarrollaban un sistema de escritura elitista que murió con ellas. Siete siglos después, [. . .] los zapotecos siguieron organizando su vida de manera oral, aunque sufriendo el peso de la dominación en español por escrito
\end{abstract}

Although the Zapotecs were a dominating culture in prehispanic times, the majority of the population organized life in an oral way while the minorities in power developed an elitist system of writing that died with them. Seven centuries later [. . .] the Zapotecs continued organizing their life in an oral way, although suffering the weight of the Spanish domination through writing.

(2002: 45)

He goes on to state that the development of Spanish-origin, text-based education did more than exclude the Indigenous population, it created a form of symbolic domination because "lo escrito descalifica lo oral, o más concretamente una cultura con escritura descalifica a las sociedades orales" [writing discredits orality, or more concretely a culture with writing discredits oral societies] (40-41). The devaluing of Indigenous communication practices was thus pervasive throughout the colonial period, with Indigenous languages viewed as inferior forms of communication, without writing or literature. The devaluing of Indigenous so-called dialectos intensified when the political tides turned to postcolonial nation-building.

\title{
2.3 Castellanización: Nationalist language ecologies
}

Following independence from Spain in 1810, a Spanish-dominant nationbuilding ideology prevailed in Mexico, with political leaders no longer ignoring the Indigenous population, but instead attempting to include and assimilate them through linguistic as well as economic means (Heath 1972). The first law establishing free primary education was passed in 1867, and in 1883 the first public primary classes were held in Juchitán, with Escuela Primaria Oficial numero 1 opening in 1890 where the Casa de la Cultura is today (Ruíz Martínez 2013). By 1895 - 376 years after the Spanish invasion - Spanish had become the language spoken by a majority of people in Mexico, a process often called castellanización, Spanish-ization (Hamel 2008a). This was not yet true of Juchitán or the 
Isthmus, however; despite the trends in the urban areas of the Mexican nationstate, many Indigenous languages remained dominant in their own regional and local spheres throughout this period.

The era of mandatory public schooling in Mexico officially began with the 1867 Ley de Instrucción Pública, although it did not become truly established until the founding and subsequent expansion of the Secretaria de Educacion Pública in 1921 (Robles 1977). The Mexican revolution in 1910-1920 resulted in a further centralist, assimilationist political environment, for which the national Secretaría de Educación Pública became a tool and support (Martínez Vásquez 2004). The first regional teacher training college in the Isthmus, the Escuela Normal Regional de Juchitán, opened in 1926 and numerous primary and secondary schools followed (Ruíz Martínez 2013). It was as a result of this aggressive national campaign for school construction and Spanish-language literacy that use of Spanish began to spread in Oaxaca in the 1940s (Hamel 2008b; Sicoli 2011). Juchitán politician Heliodoro Charis Castro, one of numerous rebelturned-politician icons who was elected mayor in 1935 and later congressman and senator, was instrumental in the creation of schools (and other public and infrastructure works) in his municipality. He was known for speaking Spanish with a heavy Zapotec accent, and is supposed to have said "niños y jovenes, estudien, porque en la vida se ganan más batallas con las letras que con las armas" [children and young people, study, because in life you win more battles with letters than with weapons]. At this time, studying was synonymous with learning Spanish. Charis Castro and other Zapotec elites were well-attuned to the power dynamics of the time, and saw the acquisition of Spanish (in addition to the locally-dominant Zapotec) as a possible resource for their community.

Despite the high hopes of political leaders like Charis Castro, mandatory public schooling perpetuated social inequalities and has largely been a space that excludes Indigenous languages and ways of knowing and being (Maldonado Alvarado 2002; Hamel 2008b). The results of Spanish-only schooling in Indigenous communities were largely poor, with many drop-outs. Alternative inclusive approaches to Indigenous education also had a presence in Mexico through pilot studies since the 1930s (Hamel 2008b) and numerous initiatives by teachers and communities. In 1978 diverse programs for Indigenous students were centralized under the Dirección General de Educación Indígena (DGEI), a branch of primary education responsible for running bilingual schools. In comparison with mainstream Spanish monolingual schools, bilingual programs typically lack resources and focus on transitioning students to Spanish rather than developing bilingualism (Hamel 2008a, 2008b; Coronado Suzán 1992) as discussed further in chapter 4. Through both so-called bilingual and mainstream 
monolingual schools, the priority of the Mexican nation-state was to spread standard Spanish and a centralized curriculum.

\subsection{Neoliberal 'multicultural' language ecologies}

The influences of economic globalization, including the effects of the North American Free Trade Agreement of 1994, which weakened the livelihoods of farmers in Oaxaca and elsewhere, have led to increased political tension and migration (López Bárecenas 2009). Residents of the Isthmus of Tehuantepec have continued their long heritage of political activism, and have organized in various social movements in response to national and international development projects (Doane 2005; Tutino 1993). These socio-economic changes are also leading to challenging shifts in the linguistic and educational landscape, including the presence of youth who speak English due to increased migration from Indigenous communities to the US and back again (Pérez Báez 2005; Zúñiga and Hamann 2015), and a growing interest in learning English. US-origin businesses, such as Wal-mart and its derivatives Sam's Club and Aurera Bodega, take business away from locally-run markets and small stores; the 4th Wal-mart-owned store in the Isthmus opened in 2014 in a part of Tehuantepec that was previously a public market. Destabilized local economies also lead to internal migration away from rural regions and towards urban centers. Extensive internal migration within Mexico and Oaxaca is resulting in mixed urban schools where students who speak Indigenous languages often do not want to admit it, and instead attempt to blend in with the Spanish mainstream (López Gopar 2009).

The effect of economic migration in the Isthmus is not as stark as in some parts of Oaxaca, however there is a different process underway, that of the arrival and rapid development of wind farms by international corporations. Since around 2007 this process is leading to land disputes (Huesca-Pérez, Sheinbaum-Pardo, and Köppel 2016), a visible presence of foreign (largely Spanish) workers, and increased stratification of Istmeño society as some landowners benefit from the developments while others resist it (Dunlap 2019). In the development of a new project in 2014, a "community consultation" between the Comisión Federal de Electricidad (CFE), the investor (a large Mexican company), and citizens of Juchitán took place as a result of Mexico's ratification of the International Labor Organization's convention 169 (International Labour Organization 1989), guaranteeing the right of previous consultation for projects on Indigenous lands. While many saw this as a farcical "consultation" with no benefits (Friede and Lehmann 2016), it is evidence of the influence of global politics on local realities in the Isthmus. 
At the national level the past few decades have seen increased rights for Indigenous communities. Beginning with the recognition of Indigenous cultural rights in the constitution in 1992, the 1996 San Andres accords achieved as a result of the Zapatista movement in Chiapas gained important ground in raising awareness of cultural and linguistic diversity in Mexico, and demanding education that is based in Indigenous cultures, rather than including them as "intercultural" tokens (Rebolledo 2010). The Coordinación General de Educación Intercultural Bilingüe (CGEIB) founded in 2001, followed by the Law on the Linguistic Rights of Indigenous Peoples in 2003 and the founding of the Instituto Nacional de Lenguas Indigenas (INALI) in 2005, are all "fruits" of the "discurso intercultural bilingüe sembrado por el zapatismo y el movimiento indígena" [intercultural bilingual discourse sown by Zapatistas and the indigenous movement] (Rebolledo 2010: 147). INALI has been engaged in training interpreters, among other language documentation and education projects, helping to make at least some changes in the way that Indigenous language speakers are treated in some public spaces. The presence of multiple languages and cultures is often lauded as a key characteristic of Oaxaca in government and tourism discourse, in particular in promotion of the yearly Guelaguetza dance festival which some view as important revenue for the state, while others view it as further exploitation of Indigenous communities.

Efforts to make "interculturalism" part of public schooling in Mexico have been deemed superficial, characterized by celebrating cultural difference without considering the hierarchies and power dynamics among groups (Velasco Cruz 2010). Even programs that might appear to have an inclusive or multiculturalist agenda, such as the recruitment and training of promotores bilingües (Indigenous bilingual classroom assistants) have followed an assimilationist agenda. Julia Noriega Sánchez, a Zapotec teacher, recounts her experience being trained as a promotora bilingüe by the Instituto de Investigación y Integración Social del Estado de Oaxaca (Institute of Research and Social Integration for the State of Oaxaca, IIISEO) as follows: "nos mandó a acabar con nuestras lenguas porque la meta era castellanizar. Al IIISEO veníamos de todo el estado de Oaxaca y teníamos la misión de acabar con nuestra cultura, con nuestra lengua" [We were told to finish off our languages, because the goal was to castillianize [spread use of Spanish]. At IIIESO we came from everywhere in the state of Oaxaca, and we had the mission to finish off our culture, our language] (Noriega Sánchez 2012: 26).

Indigenous speech communities have thus received more recognition and rights in recent decades, resulting in changes to some of the discourses that characterize language ecologies in Oaxaca, but fewer changes to the material inequalities experienced by members of these communities. Multicultural rights 
and recognition policies have been critiqued throughout Latin America for resulting in commodifying and patronizing marginalized communities, who find it impossible to claim their so-called rights in practice (Hale 2005; García 2005; Speed 2005; Overmyer-Velázquez 2010). In general there is great distrust of the government authorities among residents of the Isthmus, in particular the federal government, although the state and local government officials are often the targets of critique for corruption and the system of caciques, or powerful families who dominate political parties and regional elections. The government is assumed not to have the peoples' interest at heart, whether through a greater focus on corrupt business and trade negotiations (locally and regionally) or through prioritizing the wealthier northern regions of Mexico (nationally). In light of this it is common to turn to social networks for support (including the traditional practice of trueque, tequio, guendaruchaa or guendalisaa; communal labor and reciprocity), and for civil society groups to self-organize to attempt to provide services, including cultural and educational opportunities, which they see as lacking (see chapters 6 and 7).

This practice was in full evidence following a series of significant earthquakes that took a heavy toll in the Isthmus in September 2017, causing the collapse of many public and private buildings, and dozens of casualties. Although supplies and some support eventually arrived from government entities, an important response came from members of the community working to house and feed their neighbors, as well as private individuals from all over Mexico and internationally sending supplies to the Isthmus. Many schools were closed as a result of earthquake damage, and in addition to workshops supported by INALI and Save the Children, several local groups organized to offer workshops for children during this time. The slow reconstruction of the buildings and economy of the region is still underway as I write this book, and the long-term impacts this natural disaster may have on the region remain to be seen.

\subsection{Traditions of Indigenous language activism}

Against the backdrop of different assimilationist and multiculturalist national and regional policies, Isthmus Zapotec language advocacy initiatives have been going on within the Zapotec community since at least the late $19^{\text {th }}$ century, alongside identity-based political activism that has been going on for centuries (Tutino 1993). The language activism initiatives which are best recorded in available history are those related to writing and publishing. A group of students from Juchitán began publishing a pro-Zapotec newsletter (Neza [Path]) in Mexico City in 1935, which, albeit published largely in Spanish, included some Zapotec 
poetry and strongly pro-Zapotec rhetoric, characterized as "ferviente nacionalismo étnico de los intelectuales zapotecos" [fervent ethnic nationalism of the Zapotec intellectuals] (Miano Borruso 2002: 108). For example, an article entitled “Zapotequización” [Zapotecization] defines this term as “. . . el entrometimiento de caracteres zapotecos en el alma de las cosas o de las personas extrañas que con sólo situarse o vivir en los pueblos del Istmo juchiteco, adquieren un revestimiento peculiarmente zapoteco" [. . . the intermingling of Zapotec characteristics in the soul of the foreign things or people that, by merely situating themselves or living in the cities of the Juchitán ${ }^{12}$ Isthmus, acquire a peculiarly Zapotec covering] (Morales Henestrosa 1935). Further publications followed, and a standard orthography called the alfabeto popular [popular alphabet] was developed in 1956, spearheaded by Isthmus Zapotec writers based in Mexico City and adopted in collaboration with linguists (Pérez Báez, Cata, and Bueno Holle 2015; De Korne 2017b). The alfabeto popular was further promoted by the Casa de la Cultura, an organization in Juchitán which has been printing Zapotec poetry and other literature since being co-founded by painter and activist Francisco Toledo in 1972. The journal Guchachi’ Reza [Iguana Rajada, Sliced Iguana] was published under the direction of several different Isthmus Zapotec writers and scholars between the 1970s and 1990s, containing historical and political articles (in Spanish), art, photography, and poetry (primarily in Diidxazá) (see chapters 3 and 6 for further discussion of Zapotec literary initiatives).

While Oaxaca is among the poorest states of Mexico, the region of the Isthmus has enjoyed greater wealth and perhaps less political marginalization than other Indigenous communities. The Isthmus Zapotec have remained economically dominant in comparison with other Indigenous groups such as the Ikoots (Huave), and are demographically more numerous than any of the Zapotec communities in the mountains or central valleys of Oaxaca. They have consistently promoted their language and culture in regional and national arenas; Tehuantepec is known for the embroidered huipil (blouse), long skirts, and extravagant gold jewelry that were made famous when Frida Kahlo adopted them into her wardrobe and paintings. Juchitán is known for the election of the independent, left-wing Coalición Obrero-Campesino-Estundiantil del Istmo (COCEI, Laborerpeasant-student coalition of the Isthmus) party in 1981 at a time when the rest of the country was run by the Partido Revolucionario Institucional (Institutional Revolutionary Party, PRI), drawing the attention of political anthropologists and the

12 Referring to the Istmo juchiteco, instead of the more common Isthmus of Tehuantepec, gestures towards the long-time rivalry between the cities of Tehuantepec and Juchitán, a complex topic that will not be taken up here. 
wrath of the national government (Campbell 1989, 1994; Rubin 1994). A discourse of pride for Istmeño history, bravery, and beauty pervades much of the music and poetry composed and made popular by Istmeños. Juchitán in particular has generally received more attention from media and researchers than other parts of the Isthmus, as the base of the COCEI and a large muxe (third gender) community which has been the subject of several documentaries and numerous studies (e.g. Stephen 2002; Gosling and Osborne 2000).

Providing a backdrop and support to language and culture activities in the Isthmus, the state of Oaxaca has been home to a variety of Indigenous language advocacy organizations, including the Coordinación de Maestros y Promotores Indigenas de Oaxaca (Coordination of Indigenous Teachers and Aides of Oaxaca, CMPIO), founded in 1974, the Centro Editorial en Literatura Indígena, A.C. (Indigenous Literature Publishing Center, CELIAC), founded in 1988, and the Centro de Estudios y Desarrollo de las Lenguas Indígenas de Oaxaca (Center for studies and development of the Indigenous languages of Oaxaca, CEDELIO). There are numerous Indigenous language and culture initiatives elsewhere in the state, each with their own local particularities (Faudree 2013, 2015; Suslak 2009).

\subsection{On-going change in the language ecology}

No, yo no lo hablo tanto porque, este, mi papá siempre nos hablaba en español pero como mi abuelita siempre hablaba el zapoteco entonces al escucharlo lo entendí y lo puedo, este, pronunciar. Pero así platicarlo mucho, este, sí- Hay personas que no pueden hablar acá español y es forzosamente hablar con ellos zapoteco y ahí es donde lo hablo [. . .]-pero sî le entiendo, sí puedo.

No, I don't speak it much because, um, my dad always spoke to us in Spanish but since my granny always spoke Zapotec so through listening to it I understood it and I can, um pronounce it. But like that to speak it a lot, um, yes- there are people here that can't speak Spanish and it's necessary to speak Zapotec with them and that is where I speak it [. . . ] - but yes I understand it, yes I can.

(Interview November 2013)

This 25-year-old woman lives in La Ventosa, a village of almost 5,000 people inside the district and municipality of Juchitán, located near the center of the windswept coastal plain of the Isthmus. There are a wide range of language practices within what is generally considered the geographic and linguistic region of Isthmus Zapotec, ranging from agriculture-dependent villages where Zapotec is the dominant form of communication (such as Gui'xhi' ro', Álvaro Obregon, described in the opening of this chapter) to middle class urban centers where residents have some degree of affiliation with Isthmus Zapotec music, clothing, food, and history, but have almost no contact with Zapotec 
language use (such as Salina Cruz). As the young woman above notes, there are people who do not speak much Spanish, as well as people who do not speak Diidxazá, and people like herself in between. The presence of other Indigenous languages is also a part of the regional ecology, with Spanish as the undisputed lingua franca. The political boundaries do not follow cultural or linguistic boundaries; the sprawling municipality of Juchitán, for example, includes part of the Ombeayiüts (Huave) speaking zone; the town of Álvaro Obregon, where Isthmus Zapotec is dominant among all ages; the town of La Ventosa where most people around 30 and older speak Isthmus Zapotec; and the city of Juchitán where in the wealthier northern neighborhoods very little Zapotec is spoken, while in the poorer southern neighborhoods (in particular the "7th section") Isthmus Zapotec is used frequently and some children are acquiring it. The differing communicative repertoires, socio-economic conditions, and dialects or varieties of Isthmus Zapotec present in the Isthmus are all significant factors which inform and impact language activism in this context.

The varied communicative repertoires, described also in the opening of this chapter, are the result of shifting language socialization practices among families, influenced by the centuries of discrimination discussed in sections 2.1-2.4. Istmeño linguist Vincente Marcial Cerqueda calculates that Isthmus Zapotec is being learned by children as a first language in 2 out of 24 towns in the Isthmus (Marcial Cerqueda 2014), a result which is supported by my observations and interviews throughout the region. The map in Figure 5 represents my analysis of approximate levels of Diidxazá use by town based on observations and interviews. As I did not focus my research on the question of language vitality; this is intended as an indication of the varying levels of language use, not a precise measurement. These levels of use are nonetheless important to note because they come to have a significant effect on the language activism initiatives that are discussed in the following chapters due to the diverse repertoires of the people participating in these initiatives. The towns underlined in green in Figure 5 (San Blas Atempa, Santa Rosa, Álvaro Obergon (Gui'xhi' ro'), Santa María Xadani, and the $7^{\text {th }}$ section of Juchitán) are the areas of most dominant Isthmus Zapotec use, located primarily in the countryside and along the coast in between Juchitán and Tehuantepec. Isthmus Zapotec is spoken to varying degrees in the towns underlined in yellow (Juchitán de Zaragoza, El Espinal, Union Hidalgo, Chicapa de Castro, La Ventosa, La Mata, Asunción Ixtaltepec, Ixtepec, and San Pedro Comitancillo), but I observed generally little transmission to children. In some of these towns the youngest speakers are mature adults or older, and the town is moving towards minimal use of Diidxazá, indicated by yellow and brown underlining. The towns underlined in brown (Tehuantepec and Salina Cruz) have a cultural affinity but minimal Isthmus Zapotec use at present. 


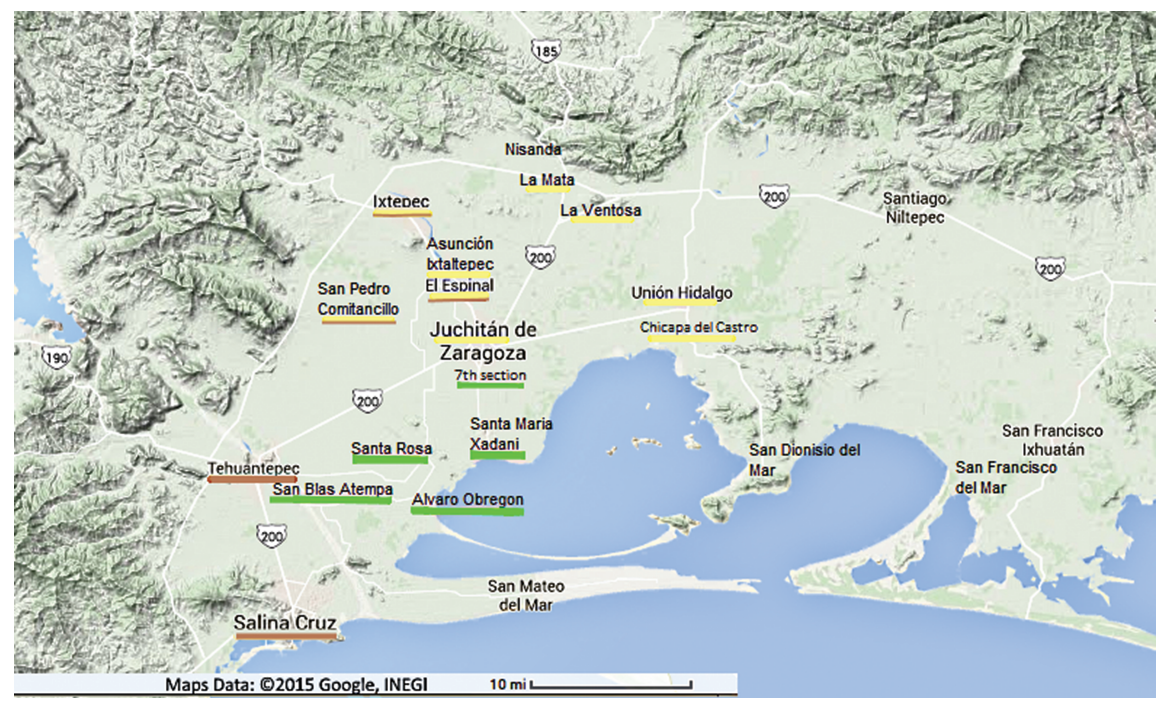

Figure 5: Geographic representation of Isthmus Zapotec use across the Isthmus.

Salina Cruz is included as a city with historical connection because they practice Isthmus Zapotec traditions such as velas, and affiliate with Isthmus Zapotec clothing, food and music, however the city grew up with a mixed populace around the development of the oil refinery in the 1970s, and has never been a Zapotec-speaking city. Tehuantepec on the other hand was a Zapotec city prior to colonization by the Aztecs in the 15th century and the Spanish in the 16th century, and continues to affiliate strongly with Zapotec culture, but only elderly people speak Diidxazá there today. Figure 5 also shows the three Ikoots (Huave) towns of San Mateo del Mar, San Dionisio del Mar and San Francisco del Mar, along the coast.

During my study I lived in the north of the city of Juchitán, a zone where Isthmus Zapotec is used among adults, but is generally not being transmitted to children. A study of Isthmus Zapotec home language socialization in Juchitán in the late 1990s found that wealthier families, while continuing to state that they wished their children to be bilingual, were raising their children mainly in Spanish (Augsburger 2004). More recent research has documented the increasing use of Spanish among children in the southern 7th section of the city, still popularly viewed as Zapotec dominant despite these ongoing changes (McComsey 2015). During my study I travelled to towns across the region in order to observe education programs and events and to conduct interviews. In almost every locale I observed adults conversing in Isthmus Zapotec amongst themselves and 
using Spanish to address children. Many interviewees and acquaintances told me that their father in particular forbade the use of Isthmus Zapotec in the home, although some eventually learned it from their mothers, grandparents, or peers in the street. Spending time with grandparents, who in many cases live with their extended families or act as primary caregivers when parents travel or live away for work, is a common way through which younger generations are acquiring at least passive comprehension abilities, as noted in the comments of the young woman above. This same phenomenon has been noted elsewhere in Mexico as the "grandparent effect" (Hill 1998; Suslak 2009). Many of the families I came to know followed a three-generation shift pattern, where the current grandparent generation speaks primarily Diidxazá, the current parents are often bilingual in Diidxazá and Spanish, and the children are dominant in Spanish, although some eventually acquire abilities as adolescents or young adults due to extended exposure to the language over time and in some cases personal motivation.

The trends of increasing socialization through Spanish documented in Juchitán are clearly present in most other towns, and correlate roughly with economic class and proximity to the railway, roads and trade routes. In Tehuantepec, the former colonial capital and commercial hub, the youngest speakers are in their 70s and 80s (Cata 2003). Ixtepec, San Pedro Comitancillo, Asunción Ixtaltepec, and El Espinal are all in proximity of railway lines, and appear to have mainly adult and senior adult speakers. ${ }^{13}$ Juchitán, La Ventosa, Union Hidalgo and La Mata are towns with a mix of economic levels, have speakers in their 20s and 30s, and older. Finally, in the rural communities of Santa María Xadani, Álvaro Obregon, and Santa Rosa, and to a lesser extent in the suburban communities of San Blas Atempa and the southern sections of Juchitán, children arrive in school speaking Zapotec, and acquire Spanish in school. As in many other minoritized language communities, the more a family is involved in economic and eventually social relations outside of the region, the more the imposed language (in this case Spanish) has come to be used (Fishman 1989).

A further important distinction to be made is that speakers of Isthmus Zapotec recognize dialect differences within the speech community, although they note that these dialects are mutually intelligible. The people who I worked with readily recognize three significant dialects which vary primarily as to vowel phonation and tone, as well as some lexical differences; the dialects of 1)

13 I spent much less time in these northern towns and interviewed fewer people from them, so my observations on this northern area of the Isthmus are more tentative than in the southern region where I spent extended time. 
Juchitán and surroundings ("los tecos”), 2) of San Blas/ Tehuantepec ("los blaseños" and "los tehuanos"), and 3) of Asunción Ixtaltepec/ La Mata ("los binni guiati”). Istmeño linguist Víctor Cata (unpublished manuscript) notes a 4th dialect in Ixtepec and San Pedro Comitancillo. Indeed, the creators of the popular alphabet in 1956 took these dialect variants into account and noted that the alphabet should be adapted to each of the regional dialects, not imposed as a monoglossic standard (see also chapters 3 and 6). These 4 dialect variants are indicated on the map in Figure 6.

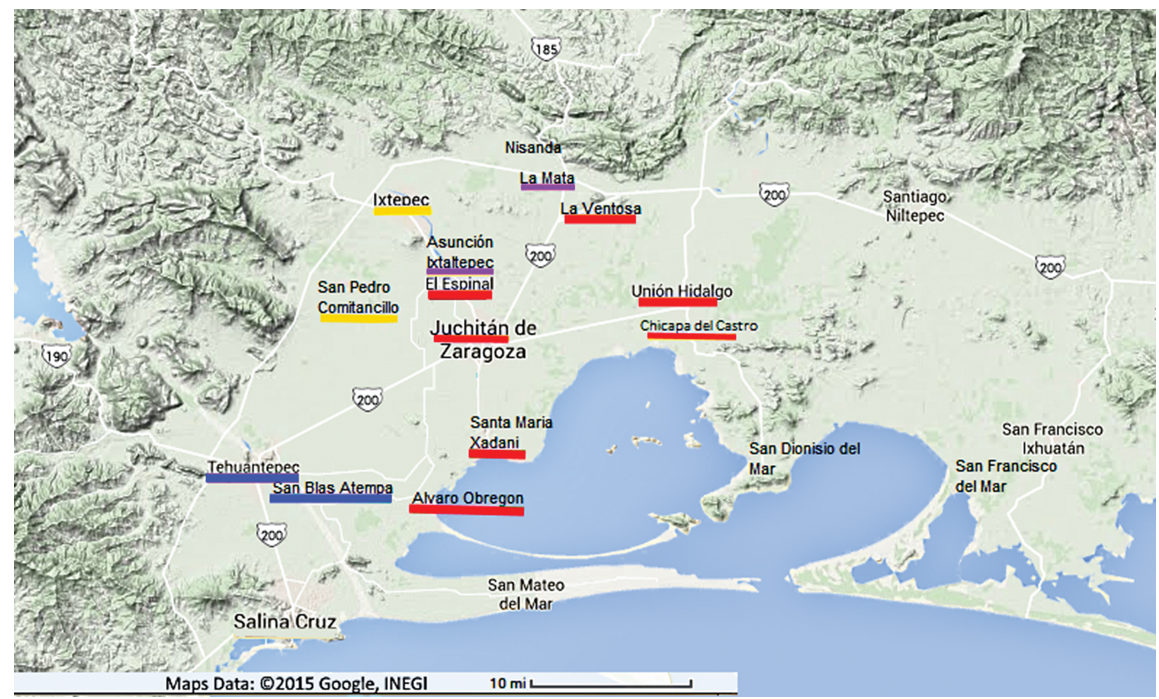

Figure 6: Geographic representation of Istmus Zapotec dialects.

Most speakers also comment that there are further differences from one town to another. Dialect variety was not a focus of my research, however I soon noted that these differences become significant in the teaching and learning of Diidxazá, as speakers from one dialect often wind up as teachers in another dialect zone, and the Juchitán dialect is the most represented in Isthmus Zapotec documentation and publications (see chapters 5 and 6).

When comparing the maps in Figures 5 and 6, it is interesting to note that what appears to most readily define the towns within the zone of greatest active Diidxazá use (around Santa María Xadani, Álvaro Obregon, Santa Rosa and San Blas Atempa) is not a political or dialect affiliation. They are split between dialects and between the municipalities of Tehuantepec and Juchitán. Rather, geographic isolation from the highway (where access roads are only partially 
paved and public transit is intermittent), participation in agriculture and fishing subsistence, and low income relative to the rest of the region are common across this area. Locally, this area is also often viewed as brava [fierce, brave], politically volatile, and an area where "good" or "pure" Diidxazá is spoken. While many people who I interacted with are aware that Isthmus Zapotec is used more in some of those towns "over there", they do not conceptualize an area or zone of active Diidxazá use as I am suggesting here; I came to view this area as a zone over time, after observing literacy workshops taught in Xadani and Álvaro Obregon, interviewing people from Xadani, San Blas, and the southern 7th section of Juchitán, and visiting schools in Xadani, Santa Rosa, Álvaro Obregon, and the 7 th section.

The linguistic diversity of the Isthmus is visible on the streets and in homes. Although Spanish text predominates in public spaces, Diidxazá is used in commercial signage and a smaller amount of official signage, as well as some public art. When entering Juchitán on any of the three main highways, visitors are greeted by a sign (see Figure 7 below) which welcomes bilingually in Spanish and Diidxazá, and shows a famous photograph by Graciela Iturbide of an Istmeña with iguanas on her head (as many women continue to carry the products that they will sell in the market). The Isthmus Zapotec translation uses one of the three common Diidxazá names for Juchitán, Lahuiguidxi (central town).

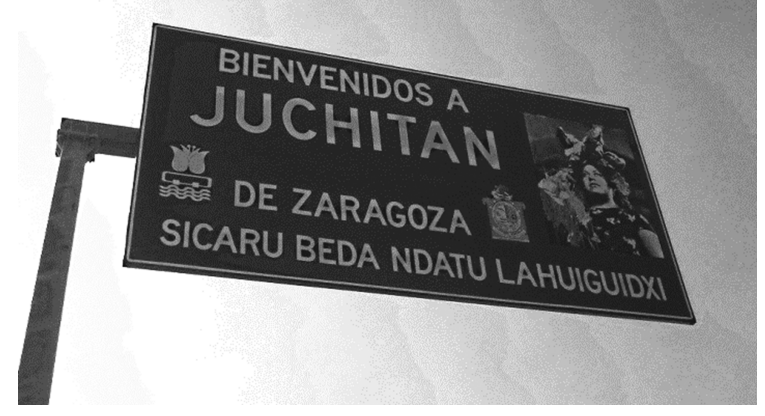

Figure 7: Sign displayed at the three main entrances to Juchitán (photo January 2014). ${ }^{14}$

Less permanent official signs, such as banners produced by the mayor's office to commemorate an event, also often include a few words or small translation of Diidxazá, although they are not usually fully bilingual. Zapotec use in commercial

14 All photos are by the author unless otherwise noted. 
signs is often limited to nouns, specifically proper nouns that give the locale (business, school, etc.) a name, rather than words which explain the function of the locale. They are thus not intended for monolingual Zapotec readers. For example, Figure 8 uses a noun to name the locale (" $B a$ 'du-huini", little child), and provides information as to the purpose of the locale, a Centro de Desarrollo Infantil, child development center, in Spanish.

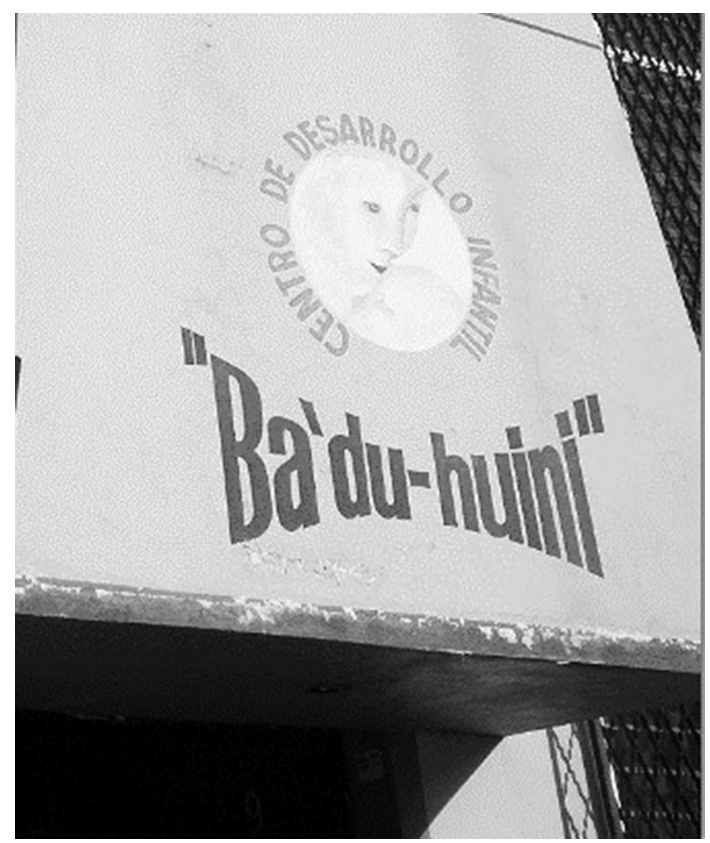

Figure 8: Centro de desarrollo infantil "Ba'du-huini" (Child development center "little child"), Juchitán (photo January 2014).

Aside from official and commercial signage, Zapotec can be observed on a sizable number of Evangelical Churches (such as Figure 9), and a smaller amount of graffiti (such as Figure 10, in an alley).

In the more private linguistic landscapes of peoples' homes, the most common texts in Diidxazá are pamphlets produced by the Jehovah's Witnesses. Invitations to parties are another common text, some of which also use Isthmus Zapotec, but are usually largely in Spanish. Finally, the popularity of social media across generations in the Isthmus is resulting in regular use of written Diidxazá on facebook and other virtual media. Isthmus Zapotec circulates on peoples' screens through memes and reproduced images, as well as through comments and direct communication (see chapter 7 for further discussion). Written use of Diidxazá in 


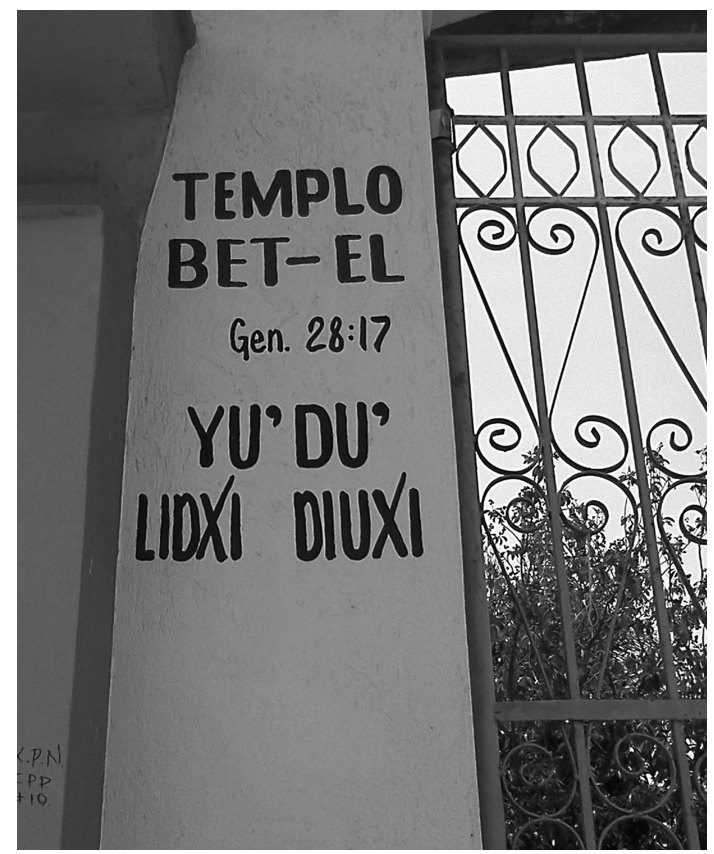

Figure 9: Yu'Du' Lidxi Diuxi (Church (sacred house) Home of God), La Ventosa (photo May 2014).

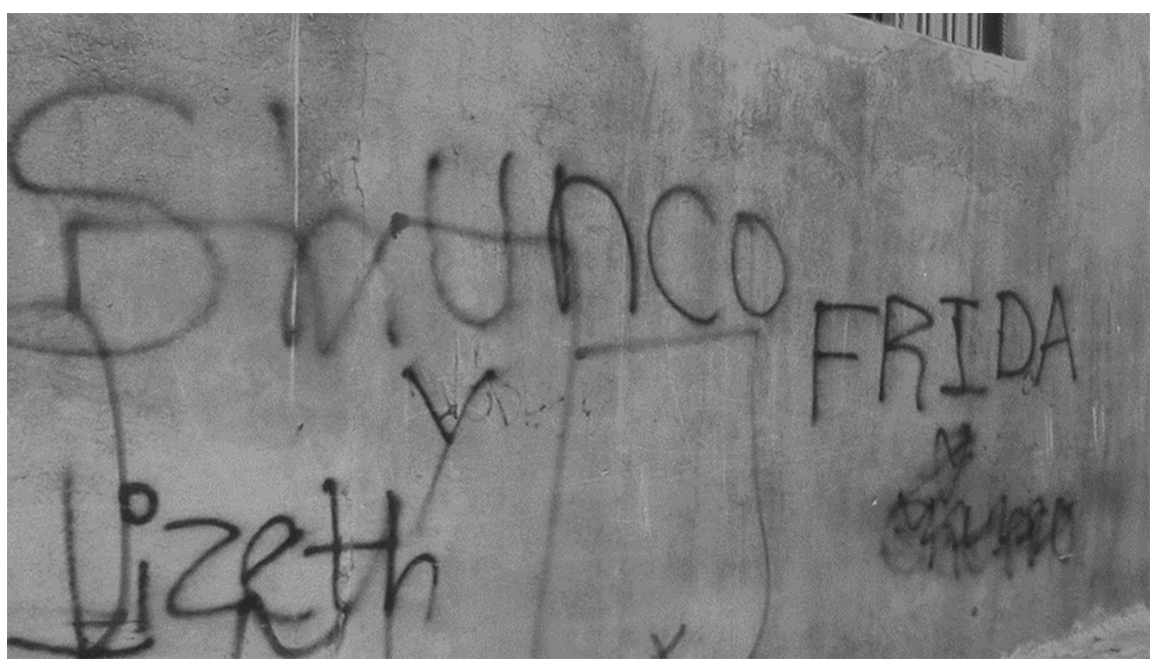

Figure 10: Shunco (Sweetheart, little one), San Blas Atempa (photo December 2013). 
both the tangible and virtual linguistic landscapes varies considerably as to orthography practices. As discussed further in chapter 6, the recognized 1956 alphabet remains unfamiliar to many people. Writing on store fronts and official signs often does conform more or less to the spelling norms of the 1956 alphabet; however writing in on-line forums does so less frequently. Diidxazá is thus a regular part of the textual lives of people in the Isthmus, alongside the de facto dominance of Spanish and the presence of English and other national and international referents.

The perspectives or ideologies which people hold in relation to both spoken and written Isthmus Zapotec vary, often in paradoxical ways. While the language and other manifestations of traditional culture such as music, folk dance and the various kinds of embroidery which characterize formal clothing are generally held in high esteem, the language in particular can also be a stereotype of lower class, a lack of education, or poverty. As the mother quoted in the opening of this chapter stated, speaking with a Zapotec accent is not wellregarded and can make people feel ashamed, so that they aspire to have their children speak like monolingual Spanish speakers. The language ideological assemblage (Kroskrity 2018) in the Isthmus thus includes discourses which value and praise Diidxazá, as well as those which link Diidxazá to problems and barriers to social mobility and well-being. Beyond the broad orientations that value or devalue Diidxazá, there are also a variety of discourses about the quality of language use. Critiques of current language use and interest in a pure or pre-colonial variety of Zapotec often arise in talk and practices around the language. A pure, uncontaminated imaginary of Zapotec is popular, in spite of the centuries of evolution, including unequal contact with Spanish, that have created "syncretic" (or fluid) language practices like those observed in Nahuatl communities in central Mexico (Hill and Hill 1986; Messing 2007). The internal diversity of Diidxazá dialects is also a topic of discussion in education settings in particular, as people question which variety is "correct" and thus the most appropriate to be taught (De Korne 2017c). These ideological currents inform different imaginaries of the future Isthmus Zapotec speech community, as well as language activism initiatives as examined further in the chapters that follow.

\subsection{Summary: Activism characteristics in changing times}

The potential supports and barriers that language activists may encounter in the Isthmus have changed over time and will continue to shift. Whether or not the increased policy support at national and international levels will eventually 
result in local improvements in the disappointing education and political systems discussed above remains to be seen. Pride for Istmeño heritage, including language, is evident historically and in public spaces today, although the influence of centuries of castellanización and discrimination remains all-toopresent as well. Indigenous language speakers have won official recognition, but many of them remain economically marginalized. The current education system, where young Istmeños spend many obligatory hours, does not promote anything more than transitional bilingualism in the majority of cases. Spanish, and increasingly English, are now added to the multilingual ecology of the Isthmus alongside the enduring use of Diidxazá and other Indigenous languages.

Like any social endeavor, language activism initiatives can only hope to succeed if they are contextually appropriate and address issues in a way which makes sense to local stakeholders. The linguistic aspirations of members of the Isthmus Zapotec community are shaped by the context described here, and include the acquisition of Spanish and English for social mobility, as well as the acquisition of Isthmus Zapotec for family communication and identity (see also De Korne 2017a). As discussed in chapter 1, linguistic equality can mean different things to different members of the speech community, who may prioritize different languages and varieties at different times. Understanding linguistic equality as a multiple and moving target may feel like a challenge to language activism, and indeed any activism, which often adopts absolute or at least explicit discourses of right and wrong in pursuit of specified goals. However, it can also be a source of strength in that goals must be justified in relation to contextualized rights and wrongs. Rather than arguing with an absolutist discourse that Indigenous languages are a treasure for all of humanity, for example, language advocates can argue with a constructivist discourse that a certain group is currently disadvantaged on the basis of language, or that they experience the lack of opportunities to use or learn their heritage language as a problem.

This gives a clear advantage to activists with a deep, personal knowledge of the local context on one hand. On the other hand, local activists may choose to collaborate with regional, national or international actors who have access to resources that they do not have, as discussed further in chapter 3. Many activism initiatives are in some way informed or supported by actors from different scales of the language ecology. For example, the Camino de la Iguana literacy workshop described in the opening of the chapter (and further discussed in chapter 6) was funded by a non-governmental foundation at the Oaxaca-state level, but developed and taught by two Juchitán-based activists. The workshops offered by INALI and Save the Children following the 2017 earthquakes employed some local people as teachers and facilitators, while the oversight and funding came 
from national and international sources. In relation to the strategy framework laid out in chapter 1, the literacy workshop had ties to both local and regional actors, although the primary location of the majority of people involved was at the local level. The INALI and Save the Children workshops also involved local actors and occurred locally, although there were links nationally and internationally which influenced the nature of the workshops.

As the language ecology of the Isthmus has shifted over time there is more influence and evidence of regional, national and international scales, and the possibility for visibility and circulation through digital platforms has increased radically. The locally-based strategies of Isthmus Zapotec writer-activists throughout the $20^{\text {th }}$ century arguably achieved strong visibility throughout the Isthmus, as the names and works of Isthmus Zapotec writers and musicians are still widely known and praised. However, there are increasing opportunities for strategies which are faster (a social media post rather than an article in a literary journal) and potentially have greater visibility (circulating on-line rather than in print). Additionally, initiatives with national or international links may achieve a higher degree of visibility in certain circles, for example through attracting the attention of the news media or publishing information on their own web platforms. However, as examined further in the chapters that follow, the characteristics of speed, visibility, and international affiliation are not always desirable; important strategies that are slow, local, and relatively private may be well-suited to certain spaces and times.

The language ecology of the Isthmus, where multiple Indigenous languages and Spanish overlap, remains a site where multilingualism is common, as it has been for centuries. This multilingualism is clearly unequal, with speakers of Indigenous languages- and furthermore certain varieties of Indigenous languages- experiencing relatively more prejudice and disadvantage than speakers of Spanish do. In the chapters that follow, I illustrate some of the imaginaries and strategies through which activists in several domains have been resisting and disrupting this inequality. Beginning with the domain of scholarly research (chapter 3), I then turn to public schooling (chapter 4), higher education (chapter 5), community-based education (chapter 6), and popular culture (chapter 7) to show how activists and advocates with local, national and international affiliations are engaging in language politics in the Isthmus. These activists are imagining and implementing strategies which draw on resources both locally and globally, over rapid and slow timescales, and in private and public ways. Some activists orient towards Isthmus Zapotec history and traditions, while others orient towards current changes and future innovations; some orient towards a unitary, 'pure' imaginary of language and culture, while others promote hybrid or syncretic imaginaries. Finally, most of these 
activists aim for open and participatory initiatives, although some degree of control or limitation is also employed as a resource in certain contexts. The initiatives of the language activists who I highlight in each domain - and many others who are not mentioned for reasons of space - show clearly that the long tradition of resistance and activism is alive and well in the Isthmus Zapotec region. 